\title{
Changes in Mammary Gland Function of Guinea Pigs within a Short Period after Delivery
}

\author{
Hiroshi NaGaSAwa \\ (Department of Animal Breeding, Faculty of Agriculture, University of Tokyo) \\ (Received for publication on February 11, 1963)
}

Many studies have been made on the ribonucleic acid content ${ }^{1-7)}$ and metabolic ${ }^{7-14}$ ) and enzymic ${ }^{15 \sim 17}$ activities of the mammary gland during pregnancy and lactation. It is suggested from these studies that the mammary gland function will show abrupt and distinct changes within a short period after delivery under the influences of endocrine and other factors. This suggestion would be very interesting in relation to the mechanism of lactogenesis. Besides, developmental changes in the lobulo-alveoli of the gland have been studied mainly with regard to the deoxyribonucleic acid content ${ }^{1 \sim 7,12,16,18-21)}$. These changes however, were investigated only at a few days' intervals, the minimum unit of time being neglected, in any of the previous studies.

The aim of the present work is to study more precisely the changes of the mammary gland function within a short period after delivery by investigating the oxygen consumption $\left(\mathrm{Qo}_{2}\right)$, respiratory quotient (R.Q.), nucleic acids (DNA-P, RNA-P) contents, and histological structure of the mammary gland for 20 hours after delivery.

\section{Materials and Methods}

Twenty-two guinea pigs from the author's stock colony were used. They were all primiparous, except two, one of which aborted on the 60th day and the other had stillbirth on the 68th day of the previous pregnancy. Both of them had been bred again in the estrus immediately after abortion or stillbirth.

It is most preferable to consider as the end of delivery the time when the last placenta leaves the uterine wall of the mother, because it is probable that one of the most important factors on the abrupt and distinct change of the mammary gland function after delivery is frustration in the balance of estrogen-progesterone level in the blood owing to the removal of the placenta. It is impossible, however, to confirm that time in practice. So the time when the last young was born was presumed to be the end of delivery in the present experiment. According to this presumption, the time necessary for delivery was mostly 20 to 30 minutes, regardless of the size of the body and the number of young.

Those animals which were at delivery and had still one or two fetuses or one to three placentas left in the uterus were classified into the O-hour group. In this group, some of the young which had been born earlier appeared to suck the milk but it was found at autopsy that there was no milk in their stomaches. The young were normally nursed till the time when experiment was performed as shown in Fig. 1.

The methods used for estimation of Qon, R.Q., RNA-P, and DNA-P and for histological observation were essentially the same as those described in the previous papers ${ }^{22,23)}$. The pituitary, adrenal, and ovary of the mother were also weighed. 


\section{Nagasawa}

\section{Results}

The results are presented in Figs. 1 and 2. The fresh and dry weights of the mammary gland and the amount of total DNA-P increased till 20 hours after delivery. The rate of increase, however, became gradually low with the lapse of time, especially in total DNA-P which reached plateau after about 10 hours.

$\mathrm{Qo}_{3} / \mathrm{DNA}-\mathrm{P}$ and RNA-P/DNA-P also increased till 20 hours after delivery, the rate of increase being more remarkable for the first 5 hours than the rest. Total $\mathrm{QO}_{2}$ and total RNA-P increased similarly, and the rates of increases were higher than those of activities per DNA-P. There was little change in R.Q., which was nearly 1 for 20 hours. The dry weight percentage decreased fairly rapidly till 5 hours and increased slightly 10 hours after delivery.

The fresh and dry weights of the mammary gland and total values of $\mathrm{QO}_{2}, \mathrm{RNA}-\mathrm{P}$ and DNA-P were considerably large in those which had aborted or had stillbirth in the previous pregnancy. No difference seemed to exist between those which finished delivery and those which were still at delivery in all measurements examined in the $\mathrm{O}$-hour group.
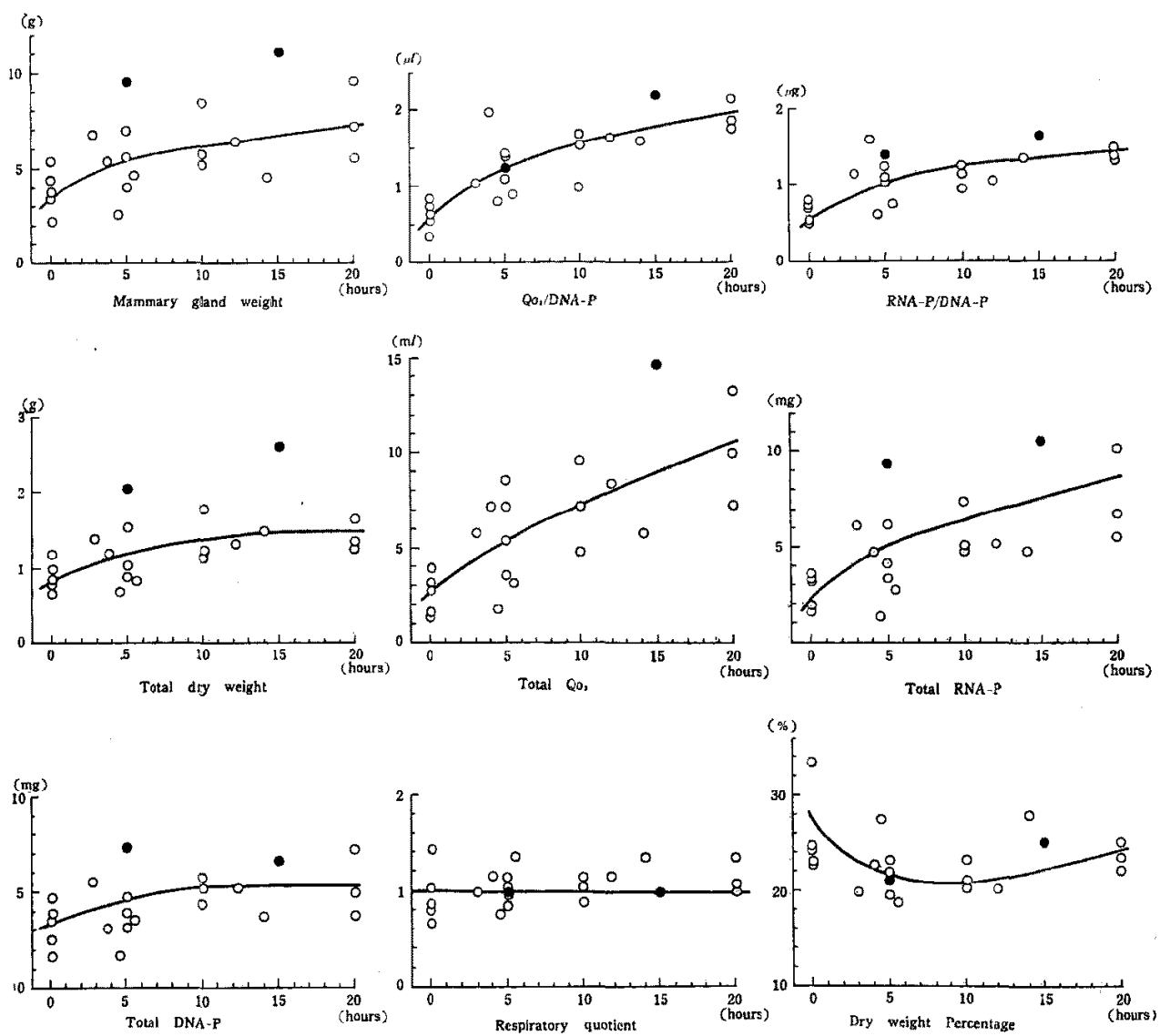

Fig. 1. Changes in measures examined

Remarks: $O=$ Individuals which normally delivered.

- Individuals which had aborted or given birth to dead young in the previous pregnancies, and which normally delivered in the present ones. 


\section{Mammary gland after delivery}

As presented in Fig. 2, histological sections from the $\mathrm{O}$-hour group showed round and small alveoli, which contained some milk-like substance in their lumina. The epithelical cells of this group were circular and compact, and appeared not so active. The alveoli, however, became larger and variable in type and size in sections after 10 hours. Cytoplasm occupied a greater part of the epithelial cell, which looked active. Furthermore, the alveoli became still larger and the epithelial cells looked much more active in 20 hours.

The weights of the pituitary, adrenal, and ovary did not always show changes with any definite tendency.
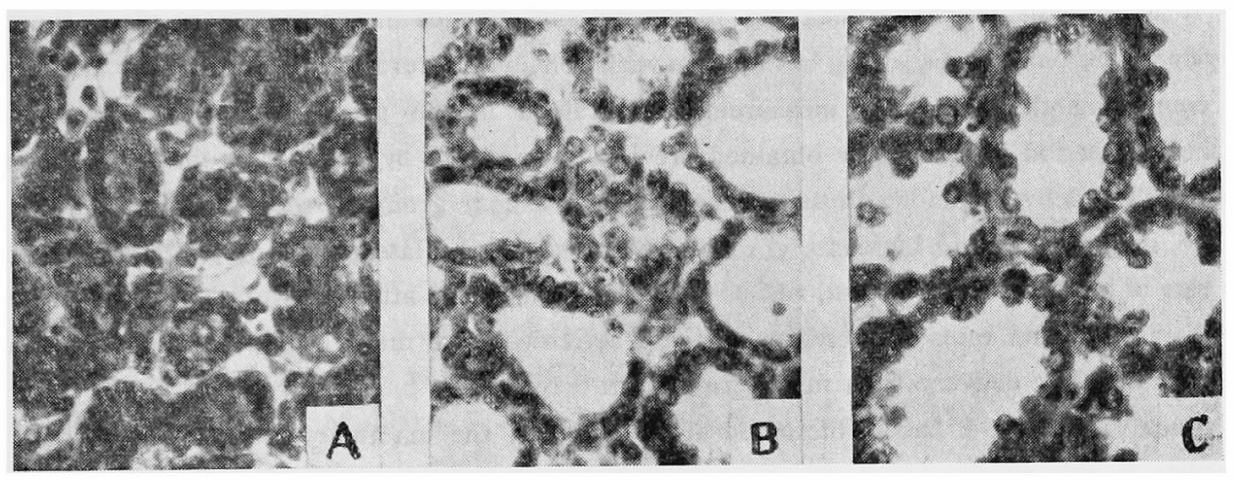

Fig. 2. Histological pictures at some stages after delivery $(\times 400)$
Remarks. A: Section from the 0-hour group.
B: Section from the 10-hour group.
C: Section from the 20 -hour group.

\section{Discussion}

The changes of $\mathrm{Qo}_{2} / \mathrm{DN} \mathrm{A}-\mathrm{P}$, RNA-P/DNA-P, and histological appearance show that the metabolic and synthetic activities of the cell increase with the lapse of time. The reasons why the rate of increase is higher for the first 5 hours than thereafter would be the beginning of suckling stimulus by the young and the completion of hormone balance for lactogenesis. It is indicated by the changes of total $\mathrm{QO}_{2}$ and total RNA-P that these activities in the whole gland also continue to increase till 20 hours, and that this increase is mainly dependent upon the increase of the activities of each cell.

The value of R.Q. remained nearly 1 till 20 hours after delivery in all the animals examined, except some in which it was lower than 1 even after delivery. In this respect, HoOVER and TURNER $^{(10)}$ reported that the R.Q. of the gland became constantly higher than 1 in the rat within 2 days after delivery. At any rate, it is presum from the present result that the lipogenic activity of the gland would be not so vigorous within these periods.

As shown in total DNA-P, the quantity of the gland parenchyma was larger in animals which had a history of abortion or stillbirth and which gave normal birth to the young in the present pregnancies than in normal primiparous ones. This was caused mainly by two reasons. One reason is that the gland which had grown during the period of previous pregnancy continued to grow without undergoing complete involution after abortion or stillbirth. The other is that the gland had higher sensitivity to the mammary-gland-stimulating hormones and grew to a 


\section{Nagasawa}

larger extent as demonstrated by YAMADA et al. ${ }^{24}$ ) It is attributed to the large quantity of the gland parenchyma that the metabolic and synthetic activities in the whole gland were higher in animals which gave normal birth after abortion or stillbirth than in normal primiparous ones, because there were no differences in these activities per DNA-P between them.

More correctly speaking, the dry weight obtained by the present method is the sum of the weight of mammary parenchyma and that of solid milk constituents. The low value of its prrcentage at about 5 hours might be, to some extent, accounted for by the gradual accumulation of milk in the gland and the increase of water content in the unit weight of mammary tissue.

It is difficult in the guinea pig to clarify any changes in the mammary gland function shortly before parturition, owing to the large variation in the duration of pregnancy. However, by comparing the values of measurements obtained in the present experiment with those in the late period of pregnancy obtained previously ${ }^{7}$ and also by considering that some animals were still at delivery among those belonging to the 0 -hour group, it seems that the function of the mammary gland increases gradually even during the late period of pregnancy, though the rate of increase is, of course, not so remarkable as that after delivery. Moreover, it is surprising that the rates of increases of these activities were much higher in a period from $\emptyset$ to 20 hours after delivery than in a period from 0 to 6 days ${ }^{7}$.

Since total DNA-P hardly increased after 10 hours, the mammary proliferation would be complete in this spacies about this hour.

\section{Summary}

Changes in the mammary gland function were studied in the guinea pig till 20 hours after delivery, by investigating oxygen consumption $\left(\mathrm{QO}_{2}\right)$, respiratory quotient (Q.Q.), nucleic acid (DNA-P, RNA-P) contents, and histological structures of the gland.

Fresh and dry weights and total DNA-P increased slightly after delivery. The rate of increase gradually decreased, especially in total DNA-P which reached a plateau after about 10 hours. Both Qo/ $/$ DNA-P and RNA-P/DNA-P increased till 20 hours, with a rate which was particularly high for the first 5 hours. Total QO2 and total RNA-P continued to increase in a similar way. R.Q. remained nearly 1 for the first 20 hours.

It was also found from the histological examination that the gland appeared to increase activity with the lapse of time.

The significance of these findings was discussed.

\section{Acknow ledgments}

The author is extremely indebted to Professor M. NAITo for his valuable advice in this work and review of the manuscript.

\section{References}

1) Kirkham, W.R. and C.W. Turner Proc. Soc. Exp. Biol. \& Med., 83: 123, 1953.

2) Shrmizu, H. Tôhoku J. Agric. Res., 7: 339, 1957.

3) Kuretani, K. Reports of Institute of Sci. Res. (Tokyo), 33: 80, 1957.

4) Greenbaum A.L. and T.F. Slater Biochem. J., 66: 155, 1957. 


\section{Mammary gland after delivery}

5) Denamur, R. Ann. Endocrinol., 22: 767, 1961.

6) Nelson, W.L., P.C. Heytler and E.I. Ciaccio Proc. Soc. Exp. Biol. \& Med., 109: 373, 1962.

7) Nagasawa, H. Jap. J. Zootech. Sci., 33: 350, 1962.

8) Folley, S.J. and T.H. French Biochem. J., 45: 270, 1949.

9) Smrth, T.C. Arch. Biochem. \& Biophys., 60: 485, 1956.

10) Hoover, C.R. and C.W. Turner Endocrinology, 54: 666, 1954.

11) Goto, I. Jap. J. Zootech. Sci., 29: 261, 1958.

12) Sмrth, T.C. and B. Richterich Arch. Biochem. \& Biophys., 74: 398, 1958.

13) Ôta, K. Jap. J. Zootech. Sci., 30: 177, 1959.

14) Linzel, J.L. J. Physiol., 153: 492, 1960.

15) Folley, S.J. and A.L. Greenbaum Biochem. J., 41: 261, 1947.

16) Lewin, I. Proc. Roy. Soc. Med., 50:563, 1957.

17) Shimizu, H. and S. Ugami Tôhoku J. Agric. Res., 10: 307, 1959.

18) Brookreson, A.D. and C.W. Turner Proc. Soc. Exp. Biol. \& Med., 102: 744, 1959.

19) GRIFFITH, D.R. and -— ibid., 102: 619, 1959.

20) Tucker, H.A. and R.P. Reece J. Dairy Sci., 45: 668, 1962.

21) Moon, R.C. Amer. J. Physiol., 203: 939, 1962.

22) Nagasawa, H. and M. Naito Jap. J. Zootech. Sci., 33: 165, 1962.

23) - - -1963.

24) Yamada, J., J. Nagar and M. Naito Endocrinol. Jap., 1: 63, 1954.

分婏直後におけるモルモットの乳腺機能の変化

長澤弘

(東京大学農学部家畜育種学教室)

分婏後 20 時間をでのモルモットの乳腺機能の变化を，

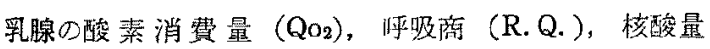
(DNA-P, RNA-P)，組織像などから検討した。

1. 生鮮おるび乾燥乳腺重量と総 DNA-P 量は, 分 婏後，同倳の傾向で増加したが，その程度は次第に弱ま り，とくに総 DNA-P 量壮，10時間目以後，ほとえど 增加老示さな加った。

2. $\mathrm{Qo}_{2} / \mathrm{DNA}-\mathrm{P}$ 括よび RNA-P/DNA-P 性, 分䅋
後堌加した。その程度汪，5時間目ごる东でが，それ以 後にくらバて著しかった。また総 $\mathrm{Q}_{2}$ 量および総 RNA$\mathrm{P}$ 量む，同様に，20 時間目まで増加を続けた。

3. RQ 法, 分娭後 20 時間目に至吉をで, 活添 1 で あった。

4. 組緎学的観察の結果からも, 乳腺の倣能は, 分婏 後, 急激に増加することがわかった。

これらの成續の意義について考察を加えた。 